\title{
Approaches to the level and quality of forage in feedlot diets for lambs
}

\begin{abstract}
Diets with low forage concentration may depress feed intake and average daily gain, while diets with high forage concentration may limit feed intake due to rumen filling. Adequate forage level may range from $7 \%$ to $14 \%$ in ration for feedlot lambs, depending on forage source and ingredient composition. Small amounts of good quality forage may improve growth performance of sheep in the first stage of fattening; however, higher energy efficiency can be obtained in feedlot lambs fed diets with low-quality roughage. Forages are required in low percentages in fattening diets for ruminants, mainly as functional ingredients, since they contribute by stimulating rumination and saliva production that reduce acidosis-related digestive disorders. The functionality of forage is influenced by its neutral detergent fiber (NDF) concentration. Feedlot cattle may have different productive performance when fed diets with constant levels of forages of different quality. These differences can be reduced when diets are formulated to contain similar NDF levels from forage. Diets for feedlot cattle formulated at $15 \%$ of NDF from forage can moderate ruminal upsets without altering feed intake; however, the optimal level might be between $4 \%$ and $8 \%$ of NDF from forage. In feedlot lambs there is limited information. Approximately $6 \%$ of NDF from forage may be included in the ration for maximum feed efficiency. At these NDF levels from forage, the forage source may have minimal influence on growth performance of feedlot animals. There are few reports on lambs on intensive feeding indicating maximum and minimum levels of NDF from forage in diets for better growth performance. This is an important scientific topic that must be considered in feedlot lambs to improve their productive performance.
\end{abstract}

Keywords: functional fiber, neutral detergent fiber, feedlot, sheep
Volume 5 Issue 3 - 2017

\author{
Salinas-Chavira J,'Arzola C, ${ }^{2}$ García-Castillo \\ $\mathrm{RF}^{3}$ B Briseño DA \\ 'Department of Animal Nutrition, Universidad Autónoma de \\ Tamaulipas, México \\ ${ }^{2}$ Department of Animal Nutrition, Universidad Autónoma de \\ Chihuahua, México \\ ${ }^{3}$ Instituto de Investigación Agropecuaria de Panamá (IDIAP), \\ Panamá
}

Correspondence: Salinas-Chavira J, Department of Anima Nutrition, Facultad de Medicina Veterinaria y Zootecnia, Universidad Autónoma de Tamaulipas, Tamaulipas, México, Email jsalinasc@hotmail.com

Received: April 06, 2017| Published: May 08, 2017
Abbreviations: NDF, neutral detergent fiber; DMI, dry matter intake; ADG, average daily gain; SS, sorghum stover; $\mathrm{AH}$, alfalfa hay

\section{Introduction}

It is possible to obtain better growth performance in lambs fed finishing diets with moderate to low levels of forage. ${ }^{1}$ However, small amounts of forage in the diet are required for better weight gain efficiency in feedlot lambs. The main benefit of forage in growing-finishing diets for feedlot lambs is the reduction of acidosis, because fiber stimulates chewing that increases saliva production, which neutralizes the acids in rumen. It is reported that feedlot cattle receiving diets with low forage level had greater amounts of rapidly fermentable carbohydrates and greater ruminal short-chain fatty acid production, although they had lower ruminal $\mathrm{pH}$ and saliva production than cattle fed diets with high forage level. ${ }^{2}$

Diets with low forage concentration may depress feed intake and average daily gain, while diets with high forage concentration can limit intake due to rumen filling. Considering that the function of the fiber is given by its NDF content, a better approach to formulation of growing-finishing diets for ruminants is based on NDF concentration in forage feed. ${ }^{3}$ Diets for feedlot cattle with different forage source (maize silage, sugar cane and sugarcane bagasse) formulated at $15 \%$ of NDF from forage can moderate ruminal upsets without altering feed intake. ${ }^{4}$ Also, the importance of using detergent fiber (NDF or ADF) analysis to measure roughage quality and consider NDF concentration in feeds in formulation of diets for feedlot cattle is recognized, considering that current methods of fiber analysis might not assess physically effective fibe. ${ }^{5}$ There is limited information on level and quality of forage used in feedlot diets for lambs to obtain optimum growth performance.

\section{Forage levels and quality in feedlot diets}

In a study used chopped hay $(0,10,20$ and $30 \%)$ in finishing diets for lambs. They reported that the dry matter intake (DMI) was higher in lambs fed $30 \%$ of hay, but the average daily gain (ADG) was lower. The increase of hay in the ration reduced the weight of carcass and its cuts, although it did not affect marbling, subcutaneous fat or weight of viscera. The increase of forage in diets resulted in greater time of feed consumption, rumination, increased rumen $\mathrm{pH}$ and the concentration of acetate. In this investigation dietary forage levels from $0 \%$ to $30 \%$ were tested; it clearly showed that $30 \%$ of forage is not adequate for feedlot lambs. ${ }^{6}$ In another study ${ }^{7}$ in feedlot lambs, 3 treatments were tested: $7 \%, 10.5 \%$ and $14 \%$ of forage in diet. No differences were observed among treatments in growth performance of lambs, concluding that in fattening sheep, the level of forage from $7 \%$ to $14 \%$ of ration may produce similar performance in feedlot lambs.

Concerning forage quality, in another study ${ }^{8}$ in fattening sheep, 3 diets (T) were tested; T1 with $0 \%$ sorghum stover (SS) and $12 \%$ alfalfa hay (AH); 2 with $9 \%$ SS plus $3 \% \mathrm{AH}$; and $\mathrm{T} 3$ with $6 \%$ SS plus $6 \%$ AH. In all the trial (1 to $60 \mathrm{~d}$ ) no effect of treatment on ADG or feed efficiency was observed; however, on the first feeding period (1 to 20d), group T1 had lower ADG than animals fed diets including alfalfa hay (T2 and T3). The authors concluded that alfalfa may improve ADG in the first stage of fattening sheep, which can be achieved with $3 \%$ alfalfa in diet. In contrast, in another study, higher energy efficiency 
for weight gain and larger visceral fat deposition were observed in lambs fed diets with low-quality roughage (sugarcane bagasse) than in animals fed diets with medium-quality roughage (Coastcross hay). These diets contained similar levels of nitrogen (2.65) and physically effective NDF (20\%). ${ }^{9}$

The main function of forage in these diets is the reduction of ruminal acidosis by increasing rumination and chewing that stimulates saliva production, which acts as a buffer of acids in rumen. This fiber functionality is provided by the content of neutral detergent fiber (NDF). In a study used different forages (alfalfa, Sudan-grass and rice straw) in finishing diets for feedlot steers. They reported that despite the marked difference in nutrient concentration in these forages, when they are incorporated into an equivalent proportion of NDF from forage (similar functional fiber) there is minimal effect on productive performance of feedlot steers. When the NDF is increased from $4 \%$ to $8 \%$, ADG is not affected but feed efficiency and dietary net energy are affected, although only moderately, $2 \%$ or less. ${ }^{10}$ In agreement, Swanson et al. ${ }^{11}$ found similar growth performance of feedlot steers fed diets with different forage sources (alfalfa hay, corn silage, wheat straw, and corn stover) when alfalfa hay was at $10 \%$ of the diet DM and the other forage sources were at the same percentage of NDF from forage. The authors also tested a mixture of hay and corn silage as the forage source at $5 \%, 10 \%, 15 \%$, or $20 \%$ forage (DM basis): they reported that greater forage levels $(>15 \%)$ had negative effect on growth performance of feedlot steers. In general, in feedlot cattle, the levels of NDF from forage must be between 6 to $9 \%$ for maximum ADG. In general terms, diets with less than $6 \%$ NDF from forage may reduce DMI and $\mathrm{ADG},{ }^{3}$ and diets with more than $9 \%$ NDF from forage may cause ruminal fill with fibrous feeds, which is translated into lower ADG.

In feedlot lambs there is limited information regarding the optimal level of NDF from forage that should be included in the ration. In a research of feedlot lambs, Flores-Mar' ${ }^{12}$ evaluated the effect of two NDF levels from forage (6 and 9\%) and two types of forage (SS and $\mathrm{AH})$ in ration on productive performance in feedlot sheep. ${ }^{12}$ In this research, the author concluded that lambs fed diets with $6 \%$ of NDF from forage showed better ADG and feed conversion compared with those fed rations with $9 \%$ of NDF from forage; it was also found that lambs fed diets with SS recorded better ADG than those fed alfalfa hay. Feedlot cattle fed diets with low quality forage (sugarcane bagasse) also showed improved growth performance compared with diets including higher quality forages (Coast cross hay).

\section{Perspectives in forage quality for feedlot lambs}

Both forage quality based on nutrient concentration and digestibility, and forage level in feedlot diets for lambs, might be ambiguous to describe the real nutritive value of forages, since better feed efficiency can be obtained using low quality forages in finishing diets, or with diets formulated at similar forage level of different forage source.

Growing-finishing diets formulated at similar NDF concentration of forage feed may produce similar growth performance in feedlot animals using different forage sources. The functionality of forages based on its NDF concentration has been studied in feedlot cattle. However, it is an important scientific topic that must be considered in feedlot lambs to improve their productive performance.

\section{Acknowledgements}

None.

\section{Conflict of interest}

Author declares that there is no conflict of interest.

\section{References}

1. Papi N, Mostafa-Tehrani A, Amanlou H, et al. Effects of dietary forage-to-concentrate ratios on performance and carcass characteristics of growing fat-tailed lambs. Anim Feed Sci Tech. 2011;163(2-4):93-98.

2. Chibisa GE, Beauchemin KA, Penner GB. Relative contribution of ruminal buffering systems to $\mathrm{pH}$ regulation in feedlot cattle fed either lowor high-forage diets. Animal. 2016;10(7):1164-1172.

3. Galyean ML, Defoor PJ. Effects of roughage source and level on intake by feedlot cattle. J Anim Sci. 2003;81(E Suppl 2):8-16.

4. Messana JD, Carvalho ALEGF, Ribeiro AF, et al. Effects of different sources of forage in high-concentrate diets on fermentation parameters, ruminal biohydrogenation and microbiota in Nellore feedlot steers. $J$ Agric Sci. 2016;154(5):928-941.

5. Samuelson KL, Hubbert ME, Galyean ML, et al. Nutritional recommendations of feedlot consulting nutritionists: The 2015 New Mexico State and Texas Tech University survey. J Anim Sci. 2016;94(6):2648-2663.

6. Fimbres H, Hernández-Vidal G, Picón-Rubio JF, et al. Productive performance and carcass characteristics of lambs fed finishing ration containing various forage levels. Small Ruminant Res. 2002;43(3):283-288.

7. Ramírez-Sánchez R, Salinas-Chavira J, Guevara-Guerrero M. Efecto del nivel de forraje y concentrado en raciones sobre el comportamiento productivo de ovinos en engorda. Memorias de XIV Congreso Nacional de la Asociación Mexicana de Técnicos Especialistas en Ovinos. México; 2008:1-5 p.

8. San Juan MR, Salinas CH J, Yado PR, et al. Efecto de la calidad de forraje sobre el comportamiento productivo de ovinos en engorda. Memorias XXXII Congreso Nacional de Buiatria. México; 2008. 462p.

9. Galvani DB, Pires AV, Susin I, et al. Energy efficiency of growing ram lambs fed concentrate-based diets with different roughage sources. $J$ Anim Sci. 2014;92(1):250-263.

10. Salinas-Chavira J, Alvarez E, Montaño MF, et al. Influence of forage NDF level, source and pelletizing on growth performance, dietary energetics, and characteristics of digestive function for feedlot cattle. Anim Feed Sci Technol. 2013;183(3-4):106-115.

11. Swanson KC, Carlson ZE, Ruch MC, et al. Influence of forage source and forage inclusion level on growth performance, feeding behavior, and carcass characteristics in finishing steers. J Anim Sci. 2017;95(3):1325-1334.

12. Flores MJ. Effect of two levels of neutral detergent fiber and two types of forage in rations on fattening behavior of lambs. Ciudad Victoria, Tamaulipas: Thesis Facultad de Medicina Veterinaria y Zootecnia, Universidad Autónoma de Tamaulipas; 2013. 